\title{
Study of Power Converter Topologies Used for Power Quality Improvement in PMSG Wind Farm Application
}

\author{
Anant Deogaonkar ${ }^{1}$, Radharaman Shaha ${ }^{2}$ \\ ${ }^{1}$ Abha Gaikwad Patil College of Engineering, Mohgaon, Nagpur, Maharashtra, India \\ ${ }^{2}$ Professor, Abha Gaikwad Patil College of Engineering, Mohgaon, Nagpur, Maharashtra, India
}

\begin{abstract}
As a source of green and abundant energy wind power is proposed as one of the main new power sources and is day by day gaining more and more importance. In last few decades, different types of wind turbines are developed to increase the maximum power capture with minimum cost and expansion for use of wind turbine for onshore and offshore applications. This paper focuses on the Power Converter Topologies used for renewable energy resources for wind farm application. In wind energy conversion system four main types of generators used are Squirrel Cage Induction Generator(SCIG), Doubly Fed Induction Generator (DFIG), Wound Field Synchronous Generator(WFSG) and Permanent Magnet Synchronous Generator (PMSG).PMSG is directly coupled to wind turbine and hence is called as Direct Driven Generator. This paper mainly discusses Power Converter Topologies in use with Permanent Magnet Synchronous Generator.
\end{abstract}

Keywords: Induction generators, Synchronous generators, onshore/offshore wind turbine, power quality, Permanent magnet generators, Power quality, multiple converters, matrix converters, z- source inverter

\section{Introduction}

Wind energy conversion system is an important and popular renewable energy technology over other different renewable energy conversion technologies [1]. Wind energy capacity has grown rapidly over the last decade and has become the fastest grown renewable energy technology [2]. Wind energy is produced by running wind turbine generator in a variable speed mode. Wind turbines are classified with a view to the rational speed, the power regulation, and the generation system. According to the construction of the drive system, the turbines are classified into the geared and the direct drive type [3], [4]. The direct drive system has advantages such as lower cost, smaller size, and weight reduction [5]. Direct drive system like PMSG has many competitive advantages over other direct drive system because of its great energy yield, noise reduction, good reliability and high efficiency [6], [7]. Currently many topologies are used in stand-alone and grid connected wind energy conversion system.

\section{Wind Energy Conversion System}

Blades of the wind turbines designed aerodynamically, they capture power from the wind and convert wind power into the mechanical power [8]. A gear box is used to match the speed of wind turbine and generator. PMSG is a direct-drive type system so it's used to eliminate the gear box and reduces the size of wind energy conversion system [9]. After converting the mechanical wind energy into electrical energy by the generator, power converters are included for conversions of generated AC power into DC power (either for storing energy in battery or supplying dc power to resistive loads) or in $\mathrm{AC} / \mathrm{DC} / \mathrm{AC}$ system supplying $\mathrm{AC}$ power grid coupled systems. Various topologies of converter used with PMSG base wind energy conversion system for high efficiency and low cost [2].

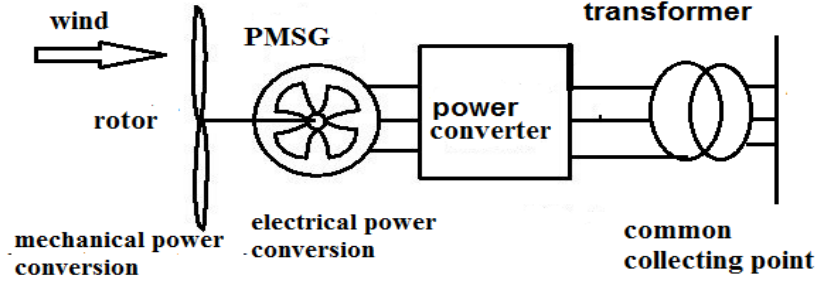

Figure 1: Wind Energy Conversion System for PMSG

\section{Power Quality Issues}

Various power quality issues that normally occur in a power system are listed below

a) Voltage Sag

- Description: A decrease of the normal voltage level between 10 and $90 \%$ of the nominal rms voltage at the power frequency, for durations of 0,5 cycle to 1 minute.

- Causes: Faults on the transmission or distribution network (most of the times on parallel feeders). Faults in consumer's installation. Connection of heavy loads and start-up of large motors.

- Consequences: Malfunction of information technology equipment, namely microprocessor-based control systems (PCs, PLCs, ASDs, etc) that may lead to a process stoppage. Tripping of contactors and electromechanical relays. Disconnection and loss of efficiency in electric rotating machines.)

\section{b) Very Short Interruptions}

- Description: Total interruption of electrical supply for duration from few milliseconds to one or two seconds.

- Causes: Mainly due to the opening and automatic reclosure of protection devices to decommission a faulty 


\section{International Journal of Science and Research (IJSR) \\ ISSN (Online): 2319-7064}

Index Copernicus Value (2013): 6.14 | Impact Factor (2015): 6.391

section of the network. The main fault causes are insulation failure, lightning and insulator flashover.

- Consequences: Tripping of protection devices, loss of information and malfunction of data processing equipment. Stoppage of sensitive equipment, such as ASDs, PCs, PLCs, if they're not prepared to deal with this situation.

\section{c) Long Interruptions}

- Description: Total interruption of electrical supply for duration greater than 1 to 2 seconds

- Causes: Equipment failure in the power system network, storms and objects (trees, cars, etc) striking lines or poles, fire, human error, bad coordination or failure of protection devices.

- Consequences: Stoppage of all equipment.

\section{d) Voltage Spike}

- Description: Very fast variation of the voltage value for durations from a several microseconds to few milliseconds. These variations may reach thousands of volts, even in low voltage.

- Causes: Lightning, switching of lines or power factor correction capacitors, disconnection of heavy loads.

- Consequences: Destruction of components (particularly electronic components) and of insulation materials, data processing errors or data loss, electromagnetic interference.

\section{e)Voltage Swell}

- Description: Momentary increase of the voltage, at the power frequency, outside the normal tolerances, with duration of more than one cycle and typically less than a few seconds.

- Causes: Start/stop of heavy loads, badly dimensioned power sources, badly regulated transformers (mainly during off-peak hours).

- Consequences: Data loss, flickering of lighting and screens, stoppage or damage of sensitive equipment, if the voltage values are too high.

\section{f)Harmonic Distortion}

- Description: Voltage or current waveforms assume nonsinusoidal shape. The waveform corresponds to the sum of different sine-waves with different magnitude and phase, having frequencies that are multiples of power-system frequency.

- Causes: Classic sources: electric machines working above the knee of the magnetization curve (magnetic saturation), arc furnaces, welding machines, rectifiers, and DC brush motors. Modern sources: all non-linear loads, such as power electronics equipment including ASDs, switched mode power supplies, data processing equipment, high efficiency lighting.

- Consequences: Increased probability in occurrence of resonance, neutral overload in 3-phase systems, overheating of all cables and equipment, loss of efficiency in electric machines, electromagnetic interference with communication systems, errors in measures when using average reading meters, nuisance tripping of thermal protections.

\section{g)Voltage Fluctuation}

- Description: Oscillation of voltage value, amplitude modulated by a signal with frequency of 0 to $30 \mathrm{~Hz}$.

- Causes: Arc furnaces, frequent start/stop of electric motors (for instance elevators), oscillating loads.

- Consequences: Most consequences are common to undervoltages. The most perceptible consequence is the flickering of lighting and screens, giving the impression of unsteadiness of visual perception.

\section{h)Noise}

- Description: Superimposing of high frequency signals on the waveform of the power-system frequency.

- Causes: Electromagnetic interferences provoked by Hertzian waves such as microwaves, television diffusion, and radiation due to welding machines, arc furnaces, and electronic equipment. Improper grounding may also be a cause.

- Consequences: Disturbances on sensitive electronic equipment, usually not destructive. May cause data loss and data processing errors.

i) Voltage Unbalance

- Description: A voltage variation in a three-phase system in which the three voltage magnitudes or the phaseangle differences between them are not equal.

- Causes: Large single-phase loads (induction furnaces, traction loads), incorrect distribution of all single-phase loads by the three phases of the system (this may be also due to a fault)

- Consequences: Unbalanced systems imply the existence of a negative sequence that is harmful to all three phase loads. The most affected loads are three-phase induction machines

\section{Power Quality Improvement Converter Topologies In Pmsg Application}

Power converters are used in WECS for converting generated power. The development of power electronics and their applicability in wind energy extraction allowed for variable speed operation of the wind turbine. Two main converter topologies of power converter with PMSG are Standalone topology and Grid connected topology.

\section{A. Grid side Converter:}

Converters used in grid side are thyristor converters. They have high power capacity and mainly used in high power applications.

\section{B. Standalone Converter:}

Standalone converter system used PWM control method general. IGBT is mainly used semi-conductor because of turn- off capability. PWM converter may produce harmonics and interharmonics due to high frequency switching. Filters are connected to remove harmonics [9].

Grid connected topologies with PMSG are classified on the basis of Grid side converters

1. Thyristor grid side converter

2. Hard switched grid side converter

3. Matrix converter

4. Multilevel converter 


\section{International Journal of Science and Research (IJSR) \\ ISSN (Online): 2319-7064}

Index Copernicus Value (2013): 6.14 | Impact Factor (2015): 6.391

\section{Z-source inverter}

\section{Thyristor grid side converter}

A thyristor grid side inverter allows continuous control of inverter firing angle [10]. To obtain the optimum energy thyristor grid side inverters regulate turbine speed by the DC link voltage. A voltage source converter (VSC) is used for the compensator and the error signal between the reference and actual compensator current is used to drive the pulse width modulated (PWM) control [11].

\section{Advantages:}

Lower cost and higher power rating.

\section{Disadvantages:}

Need of an active compensator for reactive power demand and reduction in total harmonic distortion.

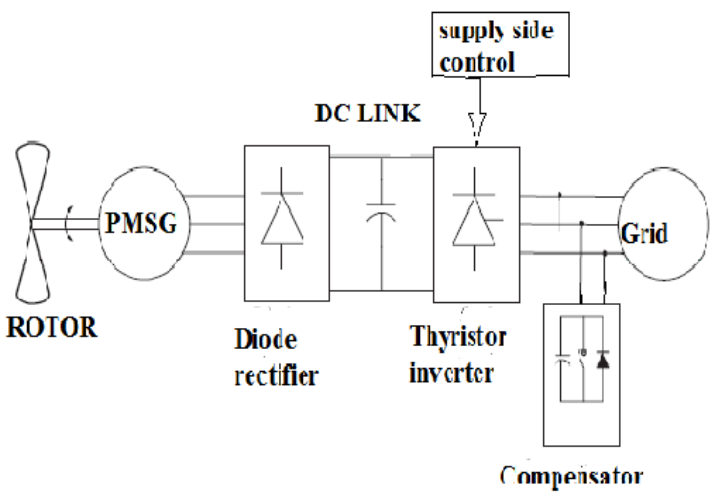

Figure 2: Thyristor Grid Side Converter

\section{Hard switched grid side converter}

To maximize the system's power output a power mapping technique is used to match the Maximum Power to the DClink voltage. Furthermore, a derivative control is also used to control the stator frequency as it changes with the DC-linked voltage. The control system is like the MPPT (Maximum Power Point Tracking) which maps the Power generated to a reference power so as to set the operating DC voltage.

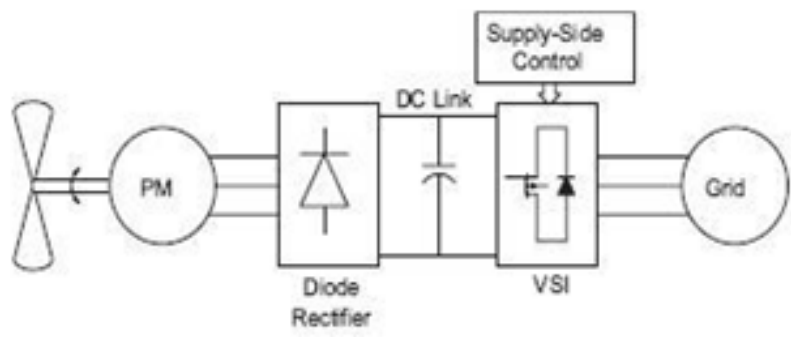

Figure 3: Hard Switching Supply Side Inverter with Voltage Source Inverter (VSI)

Following topologies are being use with grid side PWM converters:

a) Back to back PWMVSI:

Back to back PWM converter is the most conventional type converter. It is referred as two levels PWM-VSI converter because two voltage source inverter (VSI) are connected in generator side and grid side. A DC link capacitor is connected between two PWM-VSI. DC link capacitor is also called decoupling capacitor and provide a separate control in the inverter on the generator side and grid side [16].

Advantages:

- Lower cost.

Disadvantages:

- Switching losses and emission of high frequency harmonics.

- Decoupling capacitor reduces life of the system.

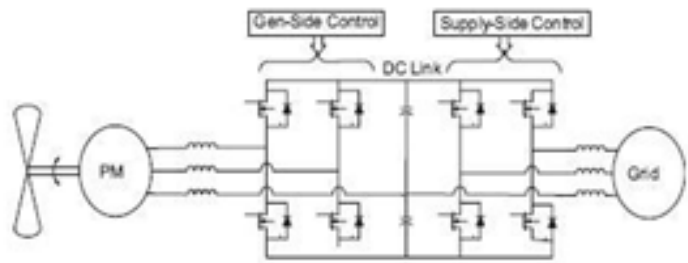

Figure 4: Back to Back PWM VSI Converter

b) Generator side uncontrolled rectifier with boost converter:

In this topology, output of PMSG is rectified by an uncontrolled rectifier and MPPT is achieved by a boost converter.

\section{Advantages:}

- No need of wind measurement.

- Controller adapts to the parameter variations of the PMSG.

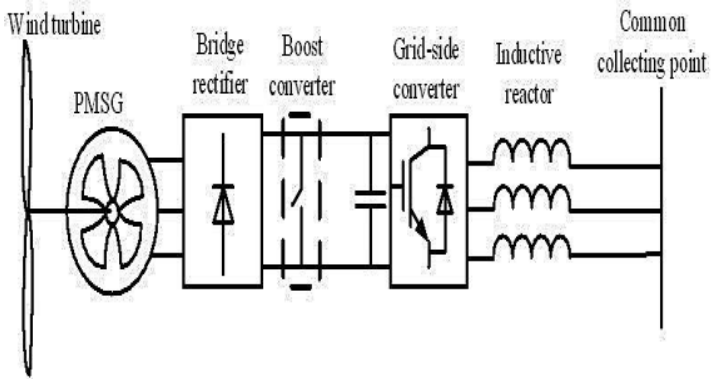

Figure 5: Generator Side Uncontrolled Rectifier With Boost Converter

c) Generator Side Phase Shifting Transformer feeding Series Type 12 Pulse Uncontrolled Rectifier:

This type of inverter used to a novel and simple MPPT control strategy. In generator terminal a passive filter is connected to reduce harmonics and improve efficiency.

\section{Advantages:}

- Provide high efficiency and suppress distortions presents in the PMSG voltage and current.

d) Generator Side semi controlled Rectifier:

The main advantages of the topology are following:

- $\quad$ Simple circuit design, no complexity.

- $\quad$ No possible shoot through fault.

- $\quad$ High efficiency.

- Low cost.

\section{Matrix converter}

Matrix converter is an AC-AC converter and an alternative of the DC link voltage-sourced converter. A matrix 


\section{International Journal of Science and Research (IJSR) \\ ISSN (Online): 2319-7064}

Index Copernicus Value (2013): 6.14 | Impact Factor (2015): 6.391

converter provides a large no. of control levers that allows for independent control on the output voltage magnitude, frequency, phase angle and input power factor [12].

\section{Advantages:}

- Eliminate DC link reactive element, e.g. bulky capacitor and / or inductors.

- No need of any large energy storage element.

- High efficiency.

- Harmonic emission.

\section{Disadvantages:}

- Lack of decoupling between the two sides of the converter.

- Low voltage gain.

- Higher conducting losses

- Due to complex control it has not accepted in industrial application.

Some different types of matrix converter are following:

\section{a) Conventional matrix converter:}

The conventional matrix converter is composed with nine bidirectional commanded insulated gate bipolar transistors (IGBT) [13]. Proper operation of switches in the matrix control on the output of magnitude, frequency, phase angle and input displacement angle.

\section{Disadvantages:}

- Commutation problem associated during the operation of the switches.

- Safe operation of the switches requires complicated switching.

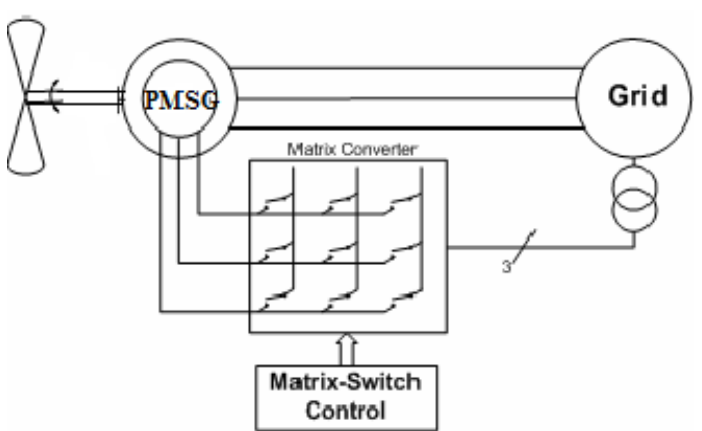

Figure 6: Conventional Matrix Converter

\section{b) Improved matrix converter}

Improved matrix converter is based on the concept "Fictitious DC link" used in controlling the matrix converter. There is no energy storage element between line side and load side converter [12]. The matrix convert is connected between two filters and PMSG is connected with first order type filter and second order type filter is connected with an electric network [13].

\section{Advantages:}

- Commutation problem associated with the switches have been solved.

- All the switches at the line-side turn-on and turn-off at Zero current

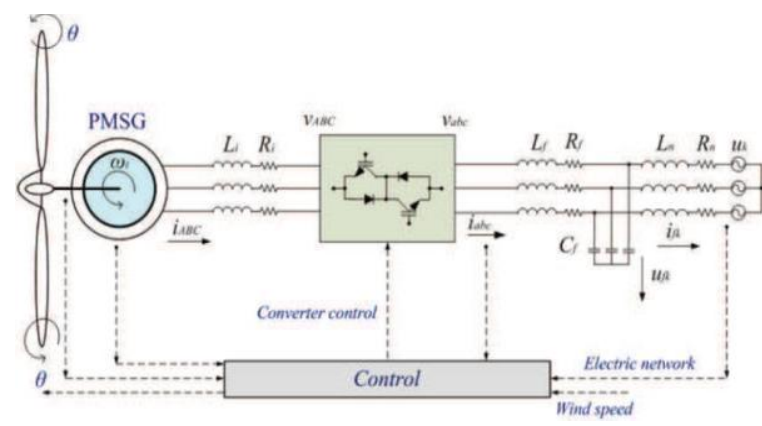

Figure 7: Improved Matrix Converter

\section{Multilevel converter}

Multilevel converters are mainly used in high power variable wind power applications [14]. Multilevel converter includes an array of power semiconductors and capacitor voltage sources, the output of which generate voltages with stepped waveform [15].

\section{Advantages}

- Divide the total voltage into multiple voltages which results in a lower $\square \square \square \square$.

- Draw input current with very low distortion.

- Can operate with a lower switching frequency and reduce switching losses.

\section{Disadvantages:}

- Voltage imbalanced due to link capacitor.

- High cost because of number of switches.

- Complex control.

- Uneven current stress on the switches due to its circuit design characteristics [16].

Types of Multilevel converters are following:

a) Neutral clamped or diode clamped converter (NPC): Neutral clamped type converter can be structured as 3-level, 5-level and even 7-level or more, the 3-level NPC is the most applied type in industry [17]. There are four switches in 3-level NPC which are applied with diodes to a midpoint of the capacitor bank. To this converter all conventional (PWM) approaches are applicable [18].

\section{Advantages:}

- The output line to line voltage of the NPC converter consist of 3 voltage level, which result in reduced harmonic in the output voltage and increase power quality.

\section{Disadvantages:}

- Power losses on the power switches are unevenly distributed which decrease the reliability of the NPC. 


\section{International Journal of Science and Research (IJSR) \\ ISSN (Online): 2319-7064}

Index Copernicus Value (2013): 6.14 | Impact Factor (2015): 6.391

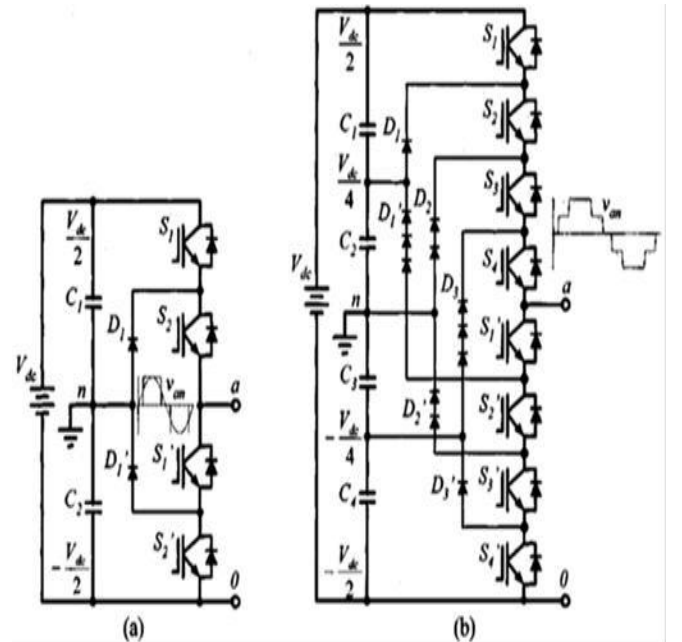

\section{Disadvantage:}

- It requires large numbers of DC sources for the H-bridge which increases the cost [18].

\section{Z-Source inverter (ZSI)}

Z-source inverter is used for maximum power tracking control and delivering power to grid [20]. ZSI is an alternative power concept as it can have both voltage buck and boost capabilities [21]. Advantages:

- $\quad$ Less effected by the EMI noise and mis-gating.

- Harmonic distortion is low.

- No of switching semiconductors is reduced.

- Reliability of the system is improved

Figure 8: Neutral clamped or diode clamped converter a)3 level b) 5 level

b) Flying capacitor converter (FCC):

Flying clamped capacitors are popular due to neutral voltage balance property. 3-level and 5-level type FCC are used in applications but 5-level type FCC is more popular because of more flexibility than a NPC.

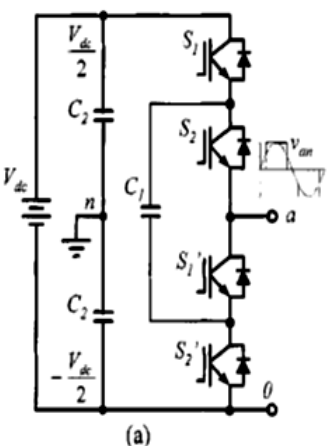

Figure 9: Flying Capacitor Converter a)3 level b)5 level

\section{c) Cascade $\mathrm{H}$ Bridge (CHB):}

Cascade $\mathrm{H}$ Bridge is a modulator converter and consists of several blocks of $\mathrm{H}$ bridge cells in series. This series connected power cells increase the voltage and power levels of the CHB. Each $\mathrm{H}$ bridge block is constructed with diodes in anti-parallel [19].
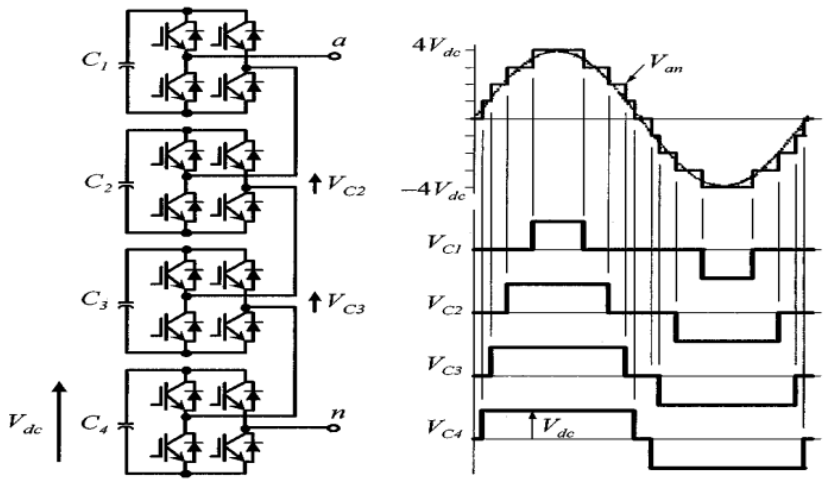

Figure 10: Clamped Capacitor Converter

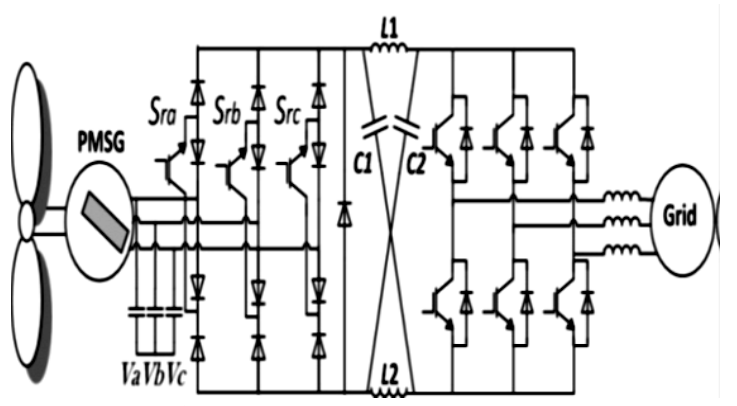

Figure 11: Z -Source Inverter

Fig. shows the main circuit of ZSI. It employs an impedance network coupled between the power sources and the converter that consists of split inductor $L_{1}$ and $L_{2}$ and capacitor $C_{1}$ and $C_{2}$ connected in $\mathrm{X}$ shape [21].

\section{Standalone Side Converter}

Main objective of the standalone wind energy conversion system is the control of load frequency and voltage [22]. Standalone system is useful in remote area where power grid is not feasible. Generally DC-DC converters are used in the standalone system. DC-DC converters are implemented between the rectifier and the battery. DC-DC converters used in standalone side are following:

1. DC boost converter.

2. DC buck-boost converter.

\section{DC boost converter}

DC boost converter is step up type converter. DC boost converters enhance the production in the high range [23]. DC-DC boost converter is used to regulate the battery bank current in order to achieve maximum power from the wind. Boost converter acts as an interface between the full wave rectifier bridge and the battery bank [24].

\section{DC buck-boost converter}

A buck-boost converter can be obtained by the cascade connection of the two basic converters, the step-down converter and the step-up converter. Buck-boost converter controls the rotor speed. 


\section{International Journal of Science and Research (IJSR)

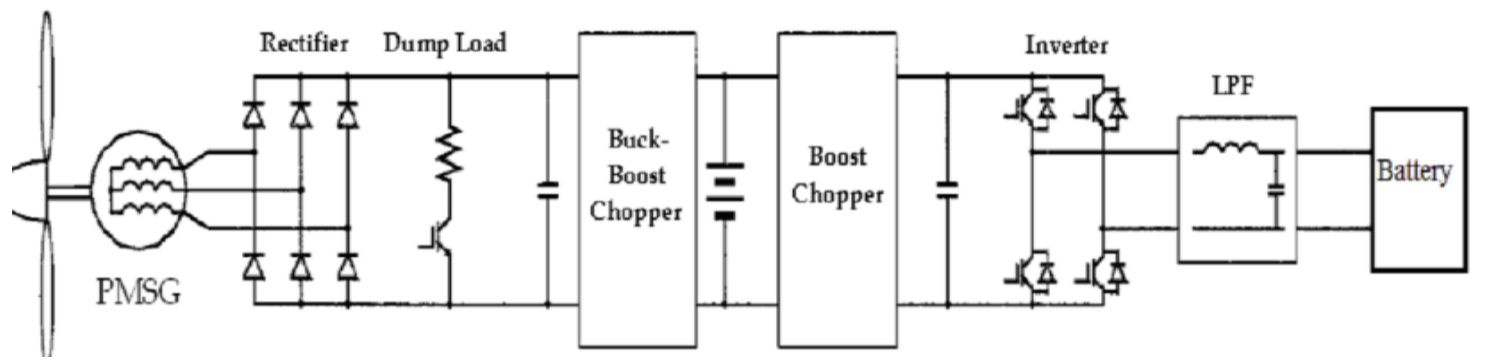

Figure 12: DC Boost \& DC Buck -Boost with PMSG

\section{Conclusion}

Wind energy conversion system (WECS) are becoming more and more popular in the renewable energy resources system. Power converter plays a important role in WECS. In this paper, different popular converter topologies used in PMSG based WECS has been studied. By studying and comparing the various converter topology of grid side and standalone system based on PMSG WECS, it is found that the Thyristor grid side inverter is cheap but generates lot of harmonics in the generator current which increased losses and reduces generator current which reduces generators life. Thyristor is not able to take out power under low wind speed condition. In hard switched inverter topology back to back PWM VSI is the most popular but it is costly solution for smaller capacity. Multilevel converter reduces the weight but they commonly used for offshore wind farms. Matrix converter eliminates the DC-link stage and provide a more reliable system comparing to other. Matrix converter has disadvantage of complicated control and cost,due to this backdraw this topology has not yet been accepted in the industrial application. Z-source inverter improves the relaibilty of the system as it is able to escape the shoot through fault. Standalone side system is used for small wind energy applications so converters used in standalone side are boost converter and buck-boost converter. Boost converter is used to convert low generated voltage into high generated voltage from small wind turbines. Buck-boost converter has cascade connection of the buck and boost converter and it is used to control the rotor speed.

\section{References}

[1] Frede Blaabjerg, Marco Liserre and KeMa, Member "Power Electronics Converters for Wind Turbine Systems" IEEE Transaction on Industry Application, Vol. 48, No. 2, March/April 2012.

[2] Faeka Khater and Alaa Omar ERI (Electronics Research Institute), Giza 12622, Egypt "A Review of Direct Driven PMSG for Wind Energy Systems" Journal of Energy and Power Engineering 7 (2013) 1592-1603.

[3] G. Sherestha, H. Polinder, D-J. Bang, J. Ferreira, Structural flexibility "A solution for weigh reduction for large direct-driven wind-turbine generators", IEEE Transaction Energy Conversion 25 (3) (2010) 732-740.

[4] An update"e, in: Proceedings of 11th WSEAS International Conference on Instrumentation, Measurements, Circuits \& Systems (IMCAS'12), Rovaniemi, Finland, Apr. 18-20, 2012, pp. 98-105.

[5] S.A. Saleh, M. Khan, M.A. Rahman, "Steady-state performance analysis and modeling of directly driven interior permanent magnet wind generators", Renewable Power Generation, IET 5 (2) (2011) 137147.

[6] M. Rosadi, S.M. Mayeen, R. Takashahi, J. Tamura, "Novel control design of variable speed PM wind generator considering gri d code requirement", in: Proceedings of 15th International Conference on Electrical Machines and Systems (ICEMS 2012), Sapporo, Japan, Oct. 22-24, 2012.

[7] H. Wang, J. Su, C. Nayar, M. Ding, "Control and inter facing of a grid-connected small-scale wind turbine generator", IEEE Transaction Energy Conversion 26 (2) (2011) 428-434.

[8] J. Marques, H. Pinheiro, H. Grundling, J. Pinheiro, H. Hey, "A Surveyon Variable - Speed Wind Turbine System," In: Proceedings of Brazilian conference of electronics of power, pp. 732-738, March 2003.

[9] E. Spooner, A.C. Williamson, "Direct coupled permanent magnet generators for wind turbine applications". In IEE Proc. Of ElectricPower Applications, Vol. 143, pp. 1-8, Jan. 1996.

[10] J. A. Baroudi, V. Dinavahi and A. M. Knight, "A review of Power Converter Topologies for Wind Generators" 0-7803-8987-5/05/, 2005 IEEE.

[11] Rishabh Dev Shukla, Prof. R. K. Tripathi, and Sandeep Gupta, "Power Electronics Applications in Wind Energy Conversion System: A Review"978-1-42448542-0/10/2010 IEEE

[12] N.Venkatesh1, G.Pandu ranga reddy, "Application of Matrix Converter in Wind Energy Conventional System Employing PMSG" IOSR Journal of Electrical and Electronics Engineering (IOSRJEEE) ISSN : 2278-1676 Volume 1, Issue 2 (May-June 2012).

[13] Rui Melício, Victor M. F. Mendes, and João P. S. Catalão, "Wind Turbines with Permanent Magnet Synchronous Generator and Full-Power Converters: Modeling, Control and Simulation" www.intechopen.com

[14] Alejandro Calle, Joan Rocabert, Sergio BusquetsMonge, Josep Bordonau, Salvador Alepuz, Joan Peracaula, "Three-Level Three-Phase Neutral-PointClamped Back-to-Back Converter Applied to a Wind Emulator

[15] José Rodríguez, Jih-Sheng Lai, Senior Member, Fang Zheng Peng, "Multilevel Inverters: A Survey of Topologies, Controls, and Applications" IEEE Transaction on Industrial Electronics, VOL. 49, NO. 4, August 2002

[16]Hyong Sik Kim, Dylan Dah-Chuan Lu, "Review on Wind Turbine Generators and Power Electronic Converters with the Grid-Connection Issues" , URL:

\section{Volume 5 Issue 6, June 2016 www.ijsr.net}




\section{International Journal of Science and Research (IJSR) \\ ISSN (Online): 2319-7064}

Index Copernicus Value (2013): 6.14 | Impact Factor (2015): 6.391

http://www.upc.edu , http://www.eupmt.es/

[17] Nantao Huang, "Simulation of Power Control of a Wind Turbine Permanent Magnet Synchronous Generator System" e-Publications@Marquette

[18] A. Nabae, I. Takahashi, and H. Akagi, "A new neutralpoint-clamped PWM inverter,'IEEE Trans. Ind. Appl., vol. IA-17, no. 5, pp. 518-523, 1981.

[19] Tor Martin Iversen,"Multilevel Converters for a 10 MW, $100 \mathrm{kV}$ Transformer-less Offshore Wind Generator System"

[20] I. Syed Meer Kula Ali, K.Raja, "Fuzzy Logic based ZSI using PMSG for WECS'International Journal of Engineering Science and Technology Vol 1, Issue 1 , 2013

[21]E.Rajendran,Dr.C.Kumar. "Power Quality improvement for Wind energy conversion systemusing and Z-source inverter", International Journal of Engineering Science and Technology

[22] Nora Lachguer and Moulay Tahar Lamchich, "Control Strategy of Permanent Magnet Synchronous Generator for Stand Alone Wind Power Generation System" 9781-4673-5003-7/11, 2011 IEEE

[23] Miguel López, Jean-Claude Vannier, "Stand-alone Wind Energy Conversion System with Maximum Power Transfer Control.

[24] Messaoud Mayouf, Rachid Abdessemed, "Comparative Study of a Small Size Wind Generation System Efficiency for Battery Charging" Serbian Journal of Electrical Enginerring Vol. 10, No. 2, June 2013, 261274

Volume 5 Issue 6, June 2016 www.ijsr.net 